See discussions, stats, and author profiles for this publication at: https://www.researchgate.net/publication/332318268

Faktualisasi Pendampingan Sosial dalam Peningkatan Usaha Ekonomi Produktif Masyarakat Miskin (Studi pada Kabupaten Buton Selatan dan Kolaka, Sulawesi Tenggara)

Conference Paper · April 2019

1 author:

A. Hasmin Tamsah

(2) Sekolah Tinggi llmu Ekonomi Amkop Makassar 24 PUBLICATIONS 12 CITATIONS

SEE PROFILE 
Seminar Nasional Pangan, Teknologi, dan Enterpreneurship "Ekspolrasi Sumberdaya Alam Hayati Indonesia Berbasis Entrepreneurship Di Era Revolusi Industri 4.0" Makassar, 09 Februari 2019

\section{Makalah Ekonomi dan Akuntansi}




\title{
Faktualisasi Pendampingan Sosial dalam Peningkatan Usaha Ekonomi Produktif Masyarakat Miskin (Studi pada Kabupaten Buton Selatan dan Kolaka, Sulawesi Tenggara)
}

\author{
Poor (Study in South Buton and Kolaka District, Southeast Sulawesi) \\ Hasmin Tamsah* ${ }^{\mathbf{1})}$, Sirajuddin ${ }^{2)}$ dan Arisandi ${ }^{3)}$ \\ 1) Program Pascasarjana STIE Amkop Makassar \\ 2) Dosen FISIP Universitas Halu Oleo Kendari \\ 3) Dinas Pekerjaan Umum Kota Makassar (KOTAKU)
}

Factualization of Social Assistance in Improving the Productive Economic Business of the

\begin{abstract}
This study aims to look at an overview of productive economic efforts and social assistance carried out at the research sites, namely in South Buton District and Kolaka, Southeast Sulawesi Province. This study used descriptive qualitative methods with independent interviewers followed by focus group discussion (FGD) on 17 informants in the South Buton District and nine informants (assistants) in Kolaka Regency and two critical informants from the social services of Southeast Sulawesi Province.

The results of the study show that: 1) The productive economic business of the poor who receive assistance from the government has gone well, with limited capacity possessed by the assistants. Productive commercial enterprises can be seen from two things, namely: a) Types, benefits, and business synchronisation; where the type of business being run must come from the recipient of assistance and synchronise with the government program. Various benefits obtained by the poor from the Ministry of Social Affairs program in the form of aid to this effort, both in the form of KUBE and UEP, including the business potential that has been owned by the poor because there is no working capital can be overcome besides the economy in the area is also increasingly passionate. b) The potential of productive economic enterprises in the two research locations is still very high, the extent of both areas characterises this, the possibility of agriculture, fisheries, energy, the trade which are still mostly untapped so that if all of these can be optimised then productive economic efforts can develop optimally. 2) Mentoring has gone well even though there are still limitations that the facilitators have, including limited coordination skills, basic abilities, analytical skills, technological utilisation abilities, and entrepreneurship skills.
\end{abstract}

Keywords: assistance, productive economic enterprises, poor

\begin{abstract}
ABSTRAK
Penelitian ini bertujuan untuk melihat gambaran usaha ekonomi produktif dan pendampingan sosial yang dilakukan pada lokasi penelitian, yaitu di Kabupaten Buton Selatan dan Kolaka Provinsi Sulawesi Tenggara. Penelitian ini menggunakan metode kualitatif deskriptif dengan indepthinterview dilanjutkan dengan focus group discussion (FGD) terhadap 17 informan (tenagapendamping) di Kabupaten Buton Selatan dan 9 informan (tenaga pendamping) di Kabupaten Kolaka serta 2 orang informan kunci dari dinas sosial Provinsi Sulawesi Tenggara. Hasil penelitian menunjukkan bahwa: 1) Usaha ekonomi produktif masyarakat miskin yang mendapat bantuan dari pemerintah sudah berjalan dengan baik, dengan keterbatasan kemampuan yang dimiliki oleh para pendamping. Usaha ekonomi produktif dapat dilihat dari dua hal, yaitu: a) Jenis, manfaat, dan singkronisasi usaha; di mana jenis usaha yang dijalankan harus berasal dari penerima bantuan dan disinkronkan dengan program pamerintah. Berbagai manfaat yang diperoleh masyarakat miskin dari adanya program Kemensos dalam bentuk bantuan untuk berusaha ini, baik berupa KUBE maupun UEP, di antaranya potensi berusaha yang sudah dimiliki oleh masyarakat miskin yang disebabkan karena tidak ada modal kerja dapat teratasi selain itu perekonomian di daerah tersebut juga semakin bergairah; b) Potensi usaha ekonomi produktif pada dua lokasi penelitian masih sangat tinggi, ini ditandai dengan luas wilayah keduanya, potensi pertanian, perikanan, energi, perdangan yang masih banyak belum tergarap sehingga bila kesemua ini dapat dioptimalkan maka usaha ekonomi produktif dapat berkembang dengan maksimal. 2) Pendampingan sudah berjalan dengan baik walaupun masih terdapat keterbatasan-keterbatasan yang dimiliki oleh para pendamping di antaranya keterbatasan kemampuan kordinasi, kemampuan dasar, kemampuan analisis, kemampuan pemanfaatan teknologi, dan kemampuan etrepreneurship.
\end{abstract}

Kata kunci: pendampingan, usaha ekonomi produktif, miskin 
Pemerintah dalam menanggulangi peningkatan angka kemiskinan, telah melakukan berbagai cara dan program, di antaranya adalah dengan pendampingan kepada masyarakat miskin. Berbagai pendampingan yang dilakukan guna membantu masyarakat miskin untuk keluar dari kemiskinan yang mereka alami, misalnya pendampingan sosial. Pendampingan adalah suatu proses pemberian kemudahan (fasilitas) yang diberikan pendamping kepada klien dalam mengidentifikasi kebutuhan dan memecahkan masalah serta mendorong tumbuhnya inisiatif dalam proses pengambilan keputusan, sehingga kemandirian klien secara berkelanjutan dapat diwujudkan (Bansos, 2007).

Pemerintah saat ini memiliki berbagai program penanggulangan kemiskinan yang terintegrasi mulai dari program penanggulangan kemiskinan berbasis bantuan sosial, program penanggulangan kemiskinan yang berbasis pemberdayaan masyarakat serta program penanggulangan kemiskinan yang berbasis pemberdayaan usaha kecil, yang dijalankan oleh berbagai elemen Pemerintah baik pusat maupun daerah. Diharapkan dengan strategi ini maka kemiskinan dapat diatasi. Berdasarkan strategi dan kelompok kerja tersebut pemerintah daerah juga melakukan hal yang sama. Hampir semua lembaga / dinas / badan pada setiap daerah termasuk di Kabupaten Buton Selatan dan Kolaka

*1) Korespondensi penulis : Hasmin Tamsah, Telp.082344149617, Email hasmin@stieamkop.ac.id 
memiliki program sebagai pengejawantahan dari program pemerintah pusat dalam mengentaskan kemiskinan. Tetapi kenyataannya masih belum optimal, hal ini terbukti dengan tingginya angka kemiskinan dan merata di seluruh provinsi di Indonesia termasuk di Sulawesi Tenggara. Inilah penyebab kemiskinan di Indonesia masih juga belum berakhir atau setidak-tidaknya berkurang secara drastis.

Masalah kemiskinan merupakan salah satu masalah utama yang dihadapi oleh hampir seluruh Negara berkembang di dunia termasuk Indonesia. Persoalan ini selalu menjadi perdebatan karena permasalahannya yang semakin kompleks. Jumlah penduduk miskin (penduduk dengan pengeluaran per kapita per bulan di bawah Garis Kemiskinan) di Indonesia mencapai 28,01 juta orang (10,86 persen), berkurang sebesar 0,50 juta orang dibandingkan dengan kondisi September 2015 yang sebesar 28,51 juta orang (11,13 persen). Sedangkan satu tahun berikutnya, yaitu September 2016 juga mengalami penurunan menjadi 27,76 juta orang (10,70 persen). Sedangkan semester berikutnya menjadi 27,77 juta orang (10,64 persen), walaupun dari segi jumlah meningkat tetapi persentasinya menurun sebesar 0,06 persen, (BPS, 2017b).

Pada sisi lain, berbagai usaha ekonomi kreatif yang muncul di tengah masyarakat, baik yang skala lokal maupun skala nasional dan bahkan skala internasional. Di tangan sebagian anak muda bangsa muncul kreativitas yang tinggi sehingga hal-hal yang tidak terpikirkan sebelumnya, tiba-tiba menjadi sebuah bisnis yang menjanjikan dan menjadi ikon di dalam masyarakat, misalnya munculnya gojek, grab, bukalapak, dll. Dua fenomena yang terjadi inilah, di mana pemerintah telah berjuang dengan berbagai program, seperti pendampingan sosial. Persoalannya adalah sejauh mana program pendampingan tersebut berjalan dan bagaimana hasilnya khususnya usaha ekonomi kreatif yang diprogramkan di Kabupaten Buton Selatan dan Kolaka. Hal inilah yang menjadi kerisauan penulis dengan mengkaji dan berusaha menjembatani dua fenomena yang disebutkan sebelumnya dengan melihat secara mendalam usaha kreatif yang ada dalam masyarakat serta usaha pemerintah dalam memberikan pendampingan sosial agar program-program yang dicanangkan dapat berjalan dengan baik.

\section{METODE PENELITIAN}

Penelitian ini dilaksanakan selama enam bulan (Juni - November 2017) dengan mewawancarai 17 informan (tenaga pendamping) di Kabupaten Buton Selatan dan 9 informan (tenaga pendamping) di Kabupaten Kolaka serta 2 orang informan kunci dari dinas sosial Provinsi Sulawesi Tenggara. Kajian ini dilakasanakan dengan menggunakan metode deskriptif kualitatif, yaitu penelitian yang menggambarkan dan melukiskan keadaan obyek penelitian pada saat sekarang sebagaimana adanya berdasarkan fakta-fakta (Moleong, 2012).

Instrumen penelitian dalam kajian ini adalah peneliti itu sendiri. Peneliti merupakan satu-satunya instrumen penelitian dalam mendapatkan informasi tentang Pendampingan Sosial dalam Meningkatkan Usaha Ekonomi Produktif Masyarakat Miskin di Kabupaten Buton Selatan dan Kabupaten Kolaka, mengacu pada (Sugiyono, 2012). Data dikumpulkan dengan teknik:

a. Observasi: teknik pengumpulan data mempunyai ciri yang spesifik bila dibandingkan dengan teknik yang lain. Observasi tidak terbatas pada orang, tetapi juga obyek-obyek alam yang lain (Sugiyono, 2009).

b. Wawancara mendalam (indepth Interview): digunakan sebagai teknik pengumpulan data untuk mengetahui hal-hal dari informan lebih mendalam. Hal ini dilakukan untuk mendapatkan jawaban yang komprehensip atas pertanyaan penelitian yang disusun sebelumnya.

c. Dokumentasi: adalah mencari data mengenai hal-hal atau variabel berupa catatan, transkip, buku, surat kabar, majalah, prasasti, notulen rapat, agenda, dan sebagainya (Arikunto, 2002). Peneliti menggunakan metode ini untuk mengumpulkan data yang sudah tersedia dalam catatan dokumen. Sebagai data 
pendukung dan pelengkap bagi data primer yang diperoleh melalui observasi dan wawancara mendalam.

d. Focus Group Discussion (FGD): metode ini untuk mengumpulkan data ialah lewatdiskusi terpusat (Focus Group Discussion), yaitu upaya menemukan makna sebuah isu oleh sekelompok orang lewat diskusi untuk menghindari diri pemaknaan yang salah oleh seorang peneliti.

Untuk keabsahan data menggunakan triangulasi dalam teknik pengumpulan data: triangulasi diartikan sebagai teknik pengumpulan data yang bersifat menggabungkan dari berbagai teknik pengumpulan data dan sumber data yang telah ada. Langkah-langkah dalam analisis data (Sugiyono, 2012) adalah sebagai berikut:

a. Reduksi data: berarti merangkum, memilih hal-hal pokok, memfokuskan hal-hal penting, dicari tema dan polanya. Data yang telah direduksi memberikan gambaran yang lebih jelas, dan mempermudah peneliti untuk melakukan pengumpulan data selanjutnya dan mencarinya bila diperlukan.

b. Penyajian data: setelah data direduksi, maka langkah selanjutnya adalah mendisplaykan data. Melalui penyajian data tersebut, maka dapat terorganisasikan, tersusun dalam pola hubungan, sehingga akan semakin mudah dipahami. Penyajian data bisa dilakukan dalam bentuk uraian singkat, bagan, hubungan antar kategori, flowchart, dan sejenisnya.

c. Penarikan kesimpulan: adalah melakukan verifikasi secara terus menerus sepanjang proses penelitian berlangsung yaitu sejak awal memasuki lokasi penelitian dan selama proses pengumpulan data. Penarikan kesimpulan dilakukan dengan pengambilan intisari dari rangkaian kategori hasil penelitian berdasarkan observasi, wawancara, serta dokumentasi hasil penelitian.

\section{HASIL DAN PEMBAHASAN}

Hasil dari berbagai interaksi langsung dengan key informan, para pendamping, dan pegawai dinas sosial (informan) di dua lokasi penelitian yaitu Kabupaten Buton Selatan dan Kolaka yang langsung bersentuhan dengan masyarakat. Berbagai informasi yang ditemukan dari lapangan penelitian selanjutnya dirangkai dalam bentuk catatan harian penelitian sebagai data awal yang kemudian dikembangkan wawancara mendalam sehingga melahirkan laporan ini. Hasil dari seluruh rangkaian metode yang digunakan dalam penelitian ini kemudian dideskripsikan dengan membagi ke dalam beberapa tema yang diangkat dari beberapa kategori yang ditemukan berulang pada semua lokasi penelitian. Kategori-kategori tersebut kemudian menjadi bahan klarifikasi dengan wawancara secara mendalam kepada informan yang hasilnya dapat disusun sebagai berikut:

\section{A. Gambaran usaha ekonomi produktif masyarakat miskin yang ada di Kabupaten Buton Selatan dan Kolaka}

Usaha ekonomi produktif adalah serangkaian kegiatan yang ditujukan untuk memberikan kemampuan usaha ekonomi, meningkatkan produktifitas kerja, meningkatkan penghasilan dan menciptakan kemitraan usaha yang saling menguntungkan yang ditujukan bagi penyandang masalah kesejahteraan sosial (PMKS) secara perorangan (Kepmensos,2007). Sedangkan tujuan akhir yang akan dicapai Kementerian Sosial tahun 2015-2019 melalui penyelenggaraan kesejahteraan sosial, adalah:

1. Meningkatkan kemampuan penduduk dalam memenuhi kebutuhan dasar;

2. Terpenuhinya hak dasar dan inklusivitas bagi penduduk miskin dan rentan, penyandang disabilitas, dan kelompok marjinal lainnya;

3. Meningkatnya kualitas manajemen dan pengelolaan penyelenggaraan kesejahteraan sosial. 
Berdasarkan hasil penelitian yang berhubungan dengan uasaha ekonomi kreatif masyarakat miskin, di antaranya:

\section{Jenis, manfaat, dan sinkronisasi usaha}

Hasil penelitian dari proses FGD dan wawancara secara mendalam terhadap informan di dua kabupaten yang dilaksanakan penelitian, menunjukkan bahwa ada beberapa kategori yang sering muncul dari pernyataan mereka, di antaranya pernyataan tentang jenis, manfaat, dan sinkronisasi program. Hasil penelitian menunjukkan bahwa penentuan jenis usaha yang akan dilaksanakan oleh para penerima bantuan ini melalui proses yang tidak mudah karena harus mempertimbangkan beberapa hal, sebagaimana yang dikemukakan oleh informan, seperti “... jenis-jenis usaha yang dikembangkan oleh anggota KUBE didasarkan pada beberapa pertimbangan, pasar dan warga yang membutuhkan produk, ketersediaan bahan baku, dan kemampuan anggota masing-masing dalam memproduksi”.

Setelah penentuan jenis usaha mereka telah sepekati kemudian proposal telah dibuat dan usaha yang ingin dijalankan telah mendapat bantuan, banyak hal yang menentukan sebuah usaha dapat berjalan dengan baik, hal ini disimpulkan dari pandangan informan, seperti, “... yang menjadi faktor penentu keberlangsungan usaha anggota KUBE adalah pengetahuan berusaha dan modal awal (sebelum disurvei), usaha, kebersamaan, jaringan yang luas. Tetapi kelompok usaha atau penerima bantuan baik kelompok atau keluarga yang gagal karena kalah bersaing dengan penjual lain, tidak konsisten dengan aturan-aturan atau kesepakatan awal mereka, individualistik, dan lain-lain”.

Lebih lanjut, beberapa informan pada kedua lokasi penelitian mengungkapkan beberapa hal penting yang telah menjadi kontribusi dengan keberadaan KUBE, seperti, “..... sebenarnya banyak manfaat dari program ini, di antaranya membuka lapangan kerja bagi warga, meningkatkan derajat kehidupan dan kualitas hidup anggota KUBE dan keluarganya, mempengaruhi percepatan perputaran ekonomi lokal desa/kelurahan, dapat menurunkan angka kemiskinan, dan juga dapat meningkatkan Pendapatan Asli Daerah (PAD)".

Dalam rangka menyusun program dan mengusulkan untuk mendapatkan bantuan, berbagai faktor yang dapat menentukan keberhasilan tersebut, di antaranya yang dikemukakan oleh para informan, “... kita susahnya itu di awal karena harus menyesuaikan antara kehendak para anggota dengan ketersediaan program yang ada, jadi para pendamping pekerjaannya yang di situ, selain memang bagaimana keinginan para calon penerima bantuan itu dapat masuk dalam program supaya program tersebut bisa sukses”.

Hasil penelitian ini sejalan dengan program awal yang galakkan oleh pemerintah bahwa kegiatan UEP disalurkan kepada masyarakat melalui kelompok-kelompok yang sudah berjalan dengan jenis kelompok peminjam digolongkan menjadi tiga (3) kelompok (Depdagri, 2002) yaitu:

1. Kelompok simpan pinjam adalah kelompok yang mengelola simpanan anggota dan pinjaman dengan tujuan untuk peningkatan kesejahteraan anggota.

2. Kelompok usaha bersama adalah kelompok yang mempunyai kegiatan usaha sejenis yang dikelola secara bersama oleh anggota kelompok.

3. Kelompok aneka usaha adalah kelompok yang anggotanya mempunyai usaha bermacam-macam atau yang dikelola secara individual oleh masing-masing anggota.

Hasil penelitian menunjukkan bahwa usaha-uasaha yang sedang berjalan saat ini adalah usaha yang sederhana dengan mengandalkan bantuan pemerintah sebesar Rp20.000.000 / kelompok atau KK. Namun demikian bila program yang dijalankan pada setiap UEP ataupun KUBE dengan baik pasti bisa meningkatkan taraf hidup mereka. Kalau beberapa pandangan yang mengatakan bahwa persoalan terbesar mereka adalah persoalan modal, maka dengan program dari Kemensos ini bisa menjawab persoalan tersebut. 
Persolan yang sering muncul adalah sebagaimana yang diungkapkan oleh para informan sebelumnya bahwa proses penentuan siapa yang berhak menerima bantuan ini juga ada masalah. Di mana di sana ada banyak kasus yang ditemukan bahwa yang sesungguhnya berhak menerima program tersebut tidak sesuai dengan kenyataan. Orang yang masuk dalam kategori fakir miskin sesuai dengan Undang Undang Republik Indonesia Nomor: 13 tahun 2011 tentang penanganan fakir muiskin khususnya pasal 1 ayat 1 yang berbunyi, "fakir miskin adalah orang yang sama sekali tidak mempunyai sumber mata pencaharian dan/atau mempunyai sumber mata pencaharian tetapi tidak mempunyai kemampuan memenuhi kebutuhan dasar yang layak bagi kehidupan dirinya dan/atau keluarganya” (UURI, 2011), namun demikian masih ada ditemukan yang tidak sesuai Undang-Undang ini seprti yang diungkapkan sebelumnya.

\section{Potensi usaha ekonomi produktif}

Usaha ekonomi produktif adalah serangkaian kegiatan yang ditujukan untuk memberikan kemampuan usaha ekonomi, meningkatkan produktifitas kerja, meningkatkan penghasilan dan menciptakan kemitraan usaha yang saling menguntungkan yang ditujukan bagi PMKS (Penyandang Masalah Kesejahteraan Sosial). Salah satu bentuk usaha ekonomi produktif yang sering dijalankan adalah program KUBE (Kelompok Usaha Bersama). Program ini dijalankan secara berkelompok dengan beranggotakan 10 sampai 20 orang per kelompok.

Dalam usaha meningkatkan pendapatan masyarakat khususnya masyarakat miskin yang dalam Undang Undang disebut sebagai fakir miskin, setiap daerah memiliki potensi yang beraneka ragam. Berdasarkan hasil observasi dan penelusuran dokumen di dua lokasi penelitian menunjukkan bahwa berbagai potensi yang dapat diubah menjadi sebuah usaha produktif. Persoalannya adalah sejauh mana masyarakat miskin tersebut memiliki jiwa wirausaha untuk melihat potensi tersebut menjadi sebauah usaha. Walaupun telah ada pendamping tetapi kemampuan pendampingpun terbatas pada peluang-peluang yang telah diajarkan, dilihat, didengarkan melalui berbagai pertemuan, bimbingan teknik, dan pelatihan lainnya.

Buton Selatan yang memilki luas wilayah 509,92 km² (BPS, 2017a) yang terdiri dari 7 Kecamatan serta garis pantai yang panjang memiliki potensi usaha ekonomi produktif di bidang perikanan yang sngat tinggi. Disamping itu kehidupan sebagai nelayan adalah pekerjaan sebagian besar penduduknya sehingga potensi semakin menjanjikan. Berdasarkan (Wikipedia, 2017) menunjukan bahwa potensi ekspor selain tambang yaitu ikan laut yang mencapai $\pm 41.168,52$ ton sehingga Kabupaten Buton Selatan merupakan jalur ikan terbesar di Indonesia. Terdapat pula potensi budidaya rumput laut yang produksinya mencapai \pm 1.258 ,89 ton. Di bidang pertanian tercatat, bahwa produksi hutanButon Selatan adalah rotan jenis batang yang memiliki luas area 150 Ha dengan total produksi 85.604 dan nilai produksinya mencapai 34.241.200. Selain itu terdapat pula perkebunan pohon palm agel yang digunakan sebagai salah satu bahan baku tali untuk dibuat menjadi aneka kerajinan, salah satunya dibuat sebagai tas tangan Agel. Di mana tas Agel ini merupakan salah satu cendera mata khas Sulawesi Tenggara.

Di bidang pertambangan misalnya, potensi ekonomi di Kabupaten Buton Selatan secara utuh memiliki tujuh potensi tambang yaitu mangan, uranium, nikel, aspal, pasir besi, marmer, dan logam mulia yang sebagian sudah menjadi komoditi ekspor, walaupun potensi ini tidak dapat dimanfaatkan dengan program ini karena investasi yang mahal. Tetapi di bidang pariwisata miasalnya, beberapa objek wisata baik wisata alam, sejarah maupun budaya menjadi daya tarik tersendiri. Seperti beberapa benteng bekas peninggalan Kesultanan Buton, adat dan tradisi masyarakat Ciacia, beberapa pantai pasir putih, lanskap yang khas, serta keindahan bawah laut Basilika (Batu Atas, Siompu, Liwutongkidi, dan Kadatua). 
Selanjutnya di bidang energi, potensi sungai Sampolawa di Kecamatan Sampolawa dengan debit 5,40 kubik per detik yang kapasitasnya mencapai 480,00 KW. Demikian maka keberadaan sumber daya air sungai Sampolawa dapat dijadikan sebagai penopang kebutuhan pasokan listrik bagi masyarakat dan pengembangan kawasan industri bagi Kabupaten Buton Selatan serta sebagai sumber air bersih dan pengairan persawahan dan lain-lain. Potensi-potensi ini kalau pemerintah Kabupaten Buton Selatan mampu manfaatkan akan menjadi sumber pendapatan asli daerah yang sangat besar. Untuk sektor pertambangan dan energi mungkin butuh investasi yang besar sehingga kreativitas pemerintah sangat dibutuhkan untuk menarik investor ke daerah ini.

Untuk potensi pemberdayaan misalnya, pemerintah dapat memanfaatkan dana dari perusahaan-perusahaan yang ada di daerah ini berupa Coorperate Social Responsibility(CSR). Selain itu potensi sektor pertanian dan perkebunan cengkeh, jambu mete merupakanandalan daerah ini. Sementara itu peternakan dan perikanan, berupa ternak sapi yang terkenal di Kecamatan Watubangga sebagai pusat ternak di Kabupaten Kolaka seperti sapi, kerbau dan kambing serta ternak unggas ayam ras. Di bidang perikanan, produksi ikan tercatat sebesar $25.373,20$ ton yang terdiri dari produksi ikan laut sebesar 19.253,30 ton dan ikan darat sebanyak 6.119,90 ton (BPS, 2017a). Potensi lainnya adalah di bidang industri dan pertambangan, perdagangan nilai jual produksi nikel juga mengalami peningkatan, dan lain-lain. Berdasarkan data-data ini maka potensi usaha ekonomi produktif di dua lokasi penelitian ini sangat besar dan potensi untuk dikembangkan, baik dalam usaha mikro kecil menengah maupun yang lebih besar.

\section{B. Gambaran kapasitas pendampingan (sumber daya, proses, dan pelaksanaan) sosial yang ada dalam meningkatkan usaha ekonomi produktif masyarakat miskin di Kabupaten Buton Selatan dan Kolaka}

Berdasarkan penelusuran dari informan yang dituangkan dalam hasil penelitian menunjukkan bahwa setiap pendamping memiliki tanggung jawab terhadap dampingan mereka. Pada bagian ini beberapa kategori yang ditemukan berulang pada semua lokasi penelitian, di antaranya:

\section{Kemampuan SDM}

Penelitian ini menunjukkan bahwa kemampuan tenaga pendamping yang dimiliki oleh Dinas Sosial Provinsi Sulawesi Tenggara khususnya yang ada pada Dinsos Kabupaten Buton Selatan dan Kelaka sudah memenuhi standar minimum sebagai pendamping. Hal ini karena prosedur perekrutan yang sudah sesuai prosedur dan seleksi yang baik, “... kami bisa jadi pendamping ini melalui seleksi, dan memenuhi berbagai persyaratan yang telah ditentukan oleh Kemensos. Ada tes tertulis dan tes yang lainnya. Mungkin saja ada yang lulus karena ada keluarga atau kenalan tetapi itupun harus melalui tes yang ada, jadi kalau memang tidak sesuai yang dipersyaratkan pasti ada yang protes”.

Perekrutan calon pendamping melalui seleksi dari Kemensos setiap dibutuhkan. Perekrutan itu disesuaikan dengan kebutuhan di seluruh wilayah Republik Indonesia. Untuk Provinsi Sulawesi Tenggara khususnya pada Kabupaten Buton Selatan dan Kolaka perekrutan sudah berjalan dengan baik. Hasil perekrutan dengan prosedur yang benar akan menghasilkan tenaga pendamping yang siap untuk bertugas dengan melihat tingkat pendidikan, keterampialan yang dimiliki, dan pengalaman mereka selama ini. Pada umumnya informan yang diteliti menunjukkan kemampuan dasar yang baik, hal ini terbukti dengan hasil kerja mereka yang telah berhasil membuat perencanaan program bagi seluruh penerima bantuan yang mereka dampingi. Namun demikian masih ada beberapa yang merasa masih perlu meningkatkan kemampuan mereka karena masih belum paham betul dengan cara membuat laporan, bagaimana cara menumbuhkan jiwa wirausaha para penerima bantuan agar usahanya lebih cepat maju, bagaimana menghadapai situasi konflik 
di antara anggota kelompok, dan lain-lain. Dengan adanya kekurangan-kekurangan yang mereka miliki inilah sehingga dapat memperlambat kerja mereka.

Pandangan ini sebagaimana yang diungkapkan oleh para informan, “... saya sudah bisa bantu mereka membuat program, menyususn proposal, dan akhirnya mereka sudah menerima bantuan modal seperti yang dijanjikan tetapi masih ada beberapa kendala yang sering terjadi dan itu butuh keterampilan khusus, misalnya pembuatan laporan setiap bulan, sering terjadi konflik antar anggota kelompok, usaha untuk menumbuhuhkan jiwa wirausaha mereka”. Hal ini sejalan dengan (Wibawa, Raharjo, \& S., 2010) menyatakan bahwa pekerja sosial adalah sebagai orang yang memiliki kewenangan keahlian dalam menyelenggarakan berbagai pelayanan sosial. Pekerja sosial adalah seseorang yang mempunyai kompetensi profesional dalam pekerjaan sosial yang diperolehnya melalui pendidikan formal atau pengalaman praktek di bidang pekerjaan sosial/kesejahteraan sosial yang diakui secara resmi oleh pemerintah dan melaksanakan tugas profesional pekerjaan sosial (Kepmensos, 2007).

Pekerja sosial sebagai penyandang keahlian pekerjaan sosial, harus memiliki kualifikasi sebagaimana yang dinyatakan oleh (Wibawa et al., 2010) sebagai berikut:

1. Memahami, menguasai, dan menghayati serta menjadi figur pemegang nilai-nilai sosio-kultural dan filsafat masyarakat.

2. Menguasai sebanyak dan sebaik mungkin berbagai perspektif teoritis tentang manusia sebagai makhluk sosial.

3. Menguasai dan secara kreatif menciptakan berbagai metode pelaksanaan tugas profesionalnya.

4. Memiliki mental wirausaha.

Kemampuan pendamping dalam melihat situasi dan kondisi masyarakat yang didampingi merupakan kebutuhan utama. Mereka harus memiliki berbagai metode dalam menghadapi berbagai sifat dan latar belakang masyarakat yang berbeda. Metode pendampingan diterapkan dalam mayoritas program sesuai kondisi dan situasi kelompok sasaran yang dihadapi. Fungsi pendamping sangat penting, terutama dalam membina dan mengarahkan kegiatan kelompok sasaran.

\section{Pelaksanaan Pendampingan}

Hasil penelitian menunjukkan bahwa para pendamping mulai dari perencanaan usaha, pembuatan proposal, penggandaan proposal, dan pengiriman, membantu penerima bantuan dengan biaya yang ditanggung sendiri oleh para pendamping. Hal ini terungkap, seperti, “... saya bantu mereka merencanakan program, hal itu saya lakukan dengan berdiskusi apa yang mereka inginkan, membantu membuat proposalnya, menggandakan, dan mengirim proposal tersebut”. Selanjutnya dikatakan bahwa “... selama perencanaan program kami sesering mungkin bertemu dengan calon penerima bantuan untuk memastikan bahwa keinginan calon penerima bantuan bisa dilakasanakan.

Pendamping memiliki tanggung jawab yang besar untuk membantu para calon penerima bantuan untuk membuat program, menerjemahkan ke dalam proposal. Setelah proposal diterima dan mendapatkan bantuan maka tugas selanjutnya adalah mendampingi dan memastikan bahwa program tersebut berjalan dengan baik dan usaha para penerima bantuan bisa sukses. Secara umum, informan sepakat bahwa intensitas pertemuan dengan penerima bantuan sangat dibutuhkan untuk saling memahami antar anggota kelompok dan antar pendamping dan penerima bantuan. Intensitas ini diyakini dapat menghilangkan sekat di antara mereka sehingga tumbuh saling percaya yang dapat mencapai tujuan dari seluruh program pemerintah yaitu pengembangan masyarakat.

Pengembangan masyarakat harus dilakukan secara holistik atau dengan multidisipliner untuk meningkatkan kesejahteraan masyarakat miskin. Selain itu, yang perlu diingat adalah bahwa manusia bersifat dinamis sehingga dapat dilakukan intervensi untuk mengembangkan masyarakat. Dinamis berarti manusia tetap menuju kebenaran dan 
tidak berhenti. Manusia tidak pernah tamat dan tidak pernah sampai pada titik selesai. Sifat dinamis ini juga menyentuh masalah evolusi dan sejarah. Pengetahuan manusia dipengaruhi oleh sejarah, lingkungan sosial, kebudayaan, dan faktor-faktor individual (Snijders, Pattison, Robins, \& Handcock, 2006). Dalam perjalanannya, pendamping diharapkan dapat mengantar kliennya untuk mandiri, hal ini diungkapkan seperti, “...dalam mendampingi penerima bantuan kita diharuskan membantu penerima untuk bisa berdiri sendiri, dapat mengkomunikasikan apa yang diinginkan, bisa menyusun program-program mereka ke depan, dan keluar dari keadaan mereka saat ini”.

Hal ini sejalan dengan unsur-unsur pengembangan masyarakat sebagaimana yang dikemukakan oleh (Efendi, 2015) antara lain:

1. Program terencana yang terfokus kepada kebutuhan-kebutuhan menyeluruh (total needs) dari masyarakat yang bersangkutan (holistik)

2. Mendorong swadaya masyarakat (empowerment)

3. Adanya bantuan teknis dari pemerintah maupun badan-badan swasta atau organisasi-organisasi sukarela, yang meliputi tenaga personil, peralatan, bahan ataupun dana (kemitraan)

4. Mempersatukan berbagai spesialisasi seperti pertanian, peternakan, kesehatan masyarakat, pendidikan, kesejahteraan keluarga, kewanitaan, kepemudaan, dan lain-lain untuk membantu masyarakat.

Selanjutnya, pendampingan adalah suatu proses pemberian kemudahan (fasilitas) yang diberikan pendamping kepada klien dalam mengidentifikasi kebutuhan dan memecahkan masalah serta mendorong tumbuhnya inisiatif dalam proses pengambilan keputusan, sehingga kemandirian klien secara berkelanjutan dapat diwujudkan (Bansos,2007). Lebih lanjut, (RI., 2009) Pendampingan sosial merupakan suatu proses relasi sosial antara pendamping dengan klien yang bertujuan untuk memecahkan masalah, memperkuat dukungan, mendayagunakan berbagai sumber dan potensi dalam pemenuhan kebutuhan hidup, serta meningkatkan akses klien terhadap pelayanan sosial dasar, lapangan kerja, dan fasilitas pelayanan publik lainnya.

Berbagai cara yang dilakukan oleh para pendamping agar esensi dari pendampingan ini dapat mencapai tujuannya, sebagaimana diungkapkan seperti, “... saya sebagai pendamping harus memikirkan berbagai cara untuk membantu para penerima bantuan dan bahkan harus menyediakan waktu untuk membimbing mereka, kadang saya harus menelpon berulang-ulang. Di lain waktu mereka menemui saya kalau memang itu tidak bisa dibicarakan melalui telepon dan saya tidak bisa mendatangi mereka”. Secara umum mereka melaksanakan berbagai langkah dengan tujuan adalah bagaimana penerima bantuan tersebut bisa berkembang sesuai dengan yang diharapkan oleh program pemerintah.

Langkah-langkah untuk mengembangkan dan meningkatkan dinamika masyarakat sebagaimana diungkapkan (Efendi, 2015) sebagai berikut:

1. Ciptakan kondisi agar potensi setempat dapat dikembangkan dan dimanfaatkan.

2. Pertinggi mutu potensi yang ada.

3. Usahakan kelangsungan kegiatan yang sudah ada.

4. Tingkatkan kesejahteraan masyarakat secara keseluruhan.

\section{Kebutuhan dan Kendala}

Pendamping dengan pengalaman yang mereka miliki mencoba meramu apa yang diinginkan oleh para calon penerima bantuan sehingga dapat merumuskan rencana usaha yang cocok dengan jumlah bantuan serta cocok dengan keinginan para calon penerima bantuan. Oleh karena itu pendamping yang memiliki pengalaman dan keterampilan yang baik akan dengan mudah membuat program yang cocok dengan jenis bantuan dan calon penerima bantuan, sebaliknya bagi pendamping yang masih baru akan memiliki keterbatasan pemahaman sehingga bisa terjadi ketidaksinkronan di antara mereka. 
Keterbatasan pendamping bukan saja pada pengetahuan dan pemahaman tentang sinkronisasi antara calon penerima dan jenis bantuan yang dijelaskan sebelumnya tetapi ada hal lain yang dapat menjadi faktor penting dalam keserasian program dengan jenis bantuan serta kesuksesan secara keseluruhan program yang diinginkan, yaitu masalah biaya untuk membuat proposal yang dalam hal ini mulai dari perencanaan, sinkronisasi antara jenis bantuan dan rencana yang diinginkan calon penerima, transportasi pendamping dari dan ke lokasi untuk memperoleh data sebagai lampiran yang dibutuhkan dalam membuat sebuah proposal. Hal ini ini terungkap seperti, “... masalahnya adalah tidak sedikit dana yang dibutuhkan untuk membuat proposal, mungkin biaya membuat tidak seberapa tetapi biaya transportasi dari rumah ke lokasi pulang-pergi, biaya penggandaan, dan biaya-biaya lainnya itu kurang lebih Rp300.000 s/d Rp500.000 per proposal, jadi bagaimana kalau harus membuat 10 proposal?”.

Sebagai pendamping yang memiliki jiwa sosial yang tinggi memang berusaha untuk membantu calon penerima bantuan dengan tujuan agar para calon penerima bantuan terakomodir dalam program sehingga resmi menjadi penerima bantuan, tidak lain adalah agar masyarakat miskin yang menjadi sasaran dari semua program Kemensos RI (program reguler), program Dinas Sosial provinsi (program fekon), dan program pemerintah daerah kabupaten/kota (program APBD). Namun demikian dengan melihat kondisi para pendamping yang pada umumnya juga memiliki kehidupan yang biasa-biasa saja (bukan dari keluarga kaya), maka biaya yang sedemikian besar akan menjadi beban bagi mereka.

Pendampingan sosial dapat didefinisikan sebagai tindakan sosial di mana penduduk sebuah komunitas mengorganisasikan diri dalam membuat perencanaan dan tindakan kolektif untuk memecahkan masalah sosial atau memenuhi kebutuhan sosial sesuai dengan kemampuan dan sumberdaya yang dimiliknya (Graha, 2009). Pendampingan sosial merupakan suatu strategi yang sangat menentukan keberhasilan program pemberdayaan masyarakat. Sesuai dengan prisip pekerjaan sosial, yakni membantu orang agar membantu dirinnya sendiri. Dalam konteks ini peranan pekerja sosial seringkali diwujudkan dalam kapasitasnya sebagai pendamping, bukan sebagai penyempuh atau pemecah masalah (problem solver) secara langsung. (Suharto, 2006).

Pendamping sosial hadir sebagai agen perubahan yang turut terlibat membantu memecahkan persoalan yang dihadapi mereka. Pendampingan sosial dengan demikian dapat diartikan sebagai interaksi dinamis antara kelompok miskin dan pekerja sosial untuk secara bersama-sama menghadapi beragam tantangan (Graha, 2009), seperti: 1) merancang program perbaikan kehidupan sosial ekonomi; 2) memobilisasi sumber daya setempat; 3) memecahkan masalah social; 4) menciptakan atau membuka akses bagi pemenuhan kebutuhan; dan 5) menjalin kerjasama dengan berbagai pihak yang relevan dengan konsep pemberdayaan masyarakat.

\section{KESIMPULAN}

Berdasarkan hasil penelitian dan pembahasan maka penelitian ini dapat disimpulkan sebagai berikut:

1. Usaha ekonomi produktif masyarakat miskin yang mendapat bantuan dari pemerintah sudah berjalan dengan baik, dan keterbatasan emampuan yang dimiliki oleh apara pendamping. Usaha ekonomi produktif dapat dilihat dari dua hal, yaitu:

a. Jenis, manfaat, dan singkronisasi usaha; di mana jenis usaha yang dijalankan harus berasal dari penerima bantuan dan disinkronkan dengan program pamerintah. Berbagai manfaat yang diperoleh masyarakat miskin dari adanya program Kemensos dalam bentuk bantuan untuk berusaha ini, baik berupa KUBE maupun UEP, di antaranya potensi berusaha yang sudah dimiliki oleh masyarakat miskin yang disebabkan karena tidak ada modal kerja dapat teratasi selain itu perekonomian di daerah tersebut juga semakin bergairah.

c. Potensi usaha ekonomi produktif pada dua lokasi penelitian masih sangat tinggi, ini ditandai dengan luas wilayah kedua, potensi pertanian, perikanan, energi, 
perdangan yang masih banyak belum tergarap sehingga bial kesemua ini dapat dioptimalkan maka usaha ekonomi produktif dapat berkembang dengan maksimal.

2. Pendampingan sudah berjalan dengan baik walaupun masih terdapat keterbatasanketerbatasan yang dimiliki oleh para pendamping di antaranya keterbatasan kemampuan kordinasi, kemampuan dasar, kemampuan analsis, kemampuan pemanfaatan teknologi, dan kemapuan jiwa etrepreneurship (jiwa kewirausahaan).

\section{DAFTAR PUSTAKA}

Arikunto, S. (2002). Metodologi Penelitian. Penerbit PT. Rineka Cipta. Jakarta.

Bansos, D. (2007). Pedoman Pendamping Pada Rumah Perlindungan dan Trauma Center. Jakarta: Departemen Sosial RI.

BPS. (2017a). Kabupaten Buton Selatan dalam Angka. from Badan Pusat Statistik, ISSN: 0215-6687, Katalog/catalog: 1102001.7404.

BPS. (2017b). Sulawesi Tenggara dalam Angka. from Badan Pusat Statistik, ISSN: 02152304, No. Publikasi/Publication Number: 74560.1701, Katalog/Catalog: 1102001.74.

Depdagri. (2002). Petunjuk Teknis Operasional, Program Pengembangan Kecamatan Tahun Anggaran 2002. Departemen Dalam Negeri, Jakarta.

Efendi, S. D. (2015). Ekonomi Kreatif: Permasalahan, Tantangan dan Prospeknya. http://www.umm.ac.id/en/opini/ekonomi-kreatif-permasalahan-tantangan-danprospeknya.html. Diakses pada 5 Desember 2017.

Kepmensos. (2007). Kepmensos Nomor: 10/HUK/2007 tentang Panduan Umum Program Kesejahteraan Sosial Anak. Kementerian Sosial Republik Indonesia.

Moleong, L. J. (2012). Metodologi Penelitian Kualitatif Edisi Revisi: Bandung: PT. Remaja Rosdakarya.

RI., D. (2009). Glosarium Penyelenggaraan Kesejahteraan Sosial. Jakarta: Pusdatin

Kesos. Snijders, T. A. B., Pattison, P. E., Robins, G. L., \& Handcock, M. S. (2006). New Specifications for Exponential Random Graph Models. Sociological Methodology, 36(1), 99-153. doi: 10.1111/j.1467-9531.2006.00176.x

Sugiyono. (2009). Metode Penelitian Bisnis (Pendekatan Kuantitatif, Kualitatif, dan R\&D): Bandung: Alfabeta.

Sugiyono. (2012). Memahami Penelitian Kualitatif: Bandung. Alfabeta.

Suharto,E. (2006). Membangun Masyarakat Membangun Rakyat. Kajian Strategis Pembangunan Sosial dan Pekerja Sosial: Bandung: Rafika Aditama.

UURI. (2011). Undang Undang Republik Indonesia Nomor: 13 tahun 2011 tentang Penanganan Fakir Miskin. Pemerintah Republik Indonesia.

Wibawa, B., Raharjo, S. T., \& S., M. B. (2010). Dasar Dasar Pekerjaan Sosial: Widya Padjadjaran: Bandung.

Wikipedia. (2017). Kabupaten Buton Selatan. from Wikipedia bahasa Indonesia ... - id Wikipedia, https://id.wikipedia.org/wiki/Kabupaten_Buton_Selatan

\section{UCAPAN TERIMA KASIH}

Melalui tulisan ini, kami mengucapkan terima kasih yang sebesar-besarnya kepada Dinas Sosial Provinsi Sulawesi Tenggara yang bekerja sama dengan Research andEmpowerment Institute (RESYS)-Kendari telah memberikan bantuan dana dalammelaksanakan penelitian ini. Terima kasih pula kepada semua pihak yang membantu terlaksananya penelitian ini, lebih khusus kepada seluruh informan dalam penelitian ini. 